\title{
CHARACTERISTICS OF LIQUID SMOKE FROM THE PYROLYSIS OF DURIAN PEEL WASTE AT MODERATE TEMPERATURES
}

\author{
M. Faisal*, A. R. Yelvia Sunarti, and Hera Desvita \\ Department of Chemical Engineering, Syiah Kuala University, Banda Aceh, 23111, Indonesia \\ J1. Syech A Rauf No 7 Darussalam, Banda Aceh, 23111 Indonesia \\ *E-mail : mfaisal@unsyiah.ac.id
}

\begin{abstract}
As a tropical country, Indonesia possesses abundant natural resources including a variety of plants. One of these interesting plants is durian (Durio zibethinus), which produces a large amount of biomass waste. High durian consumption results in a significant amount of peel waste. Similar to other biomass waste, durian peel contains cellulose, hemicellulose, and lignin, which are the main components that form liquid smoke. Durian peel pyrolysis is one method that can be used to produce liquid smoke, which can be used as a natural preservative, latex coagulant, and biopesticide. This research aimed to characterize liquid smoke generated from durian peel waste at moderate temperatures using the slow pyrolysis method. The batch reactor that was used has a $5 \mathrm{~kg}$ capacity and was run at temperatures of $300^{\circ} \mathrm{C}, 340^{\circ} \mathrm{C}$, and $380^{\circ} \mathrm{C}$. The chemical compounds contained in the liquid smoke were tested quantitatively using gas chromatography-mass spectrometry (GC-MS). The acetic acid and phenol were tested, qualitatively, using high performance liquid chromatography (HPLC). GC-MS results showed that more than 15 chemical compounds were detected in the liquid smoke, including phenolic acid, carbonyl, carboxylate, furan, and acid compounds, among others. The pyrolysis temperature greatly influences the resulting liquid smoke components, especially the composition of phenol and acetate. The highest phenol content $(2 \%)$ was found in the liquid smoke that resulted from pyrolysis at $300^{\circ} \mathrm{C}$; while the highest acetic acid content (8\%) was found in the liquid smoke that resulted from pyrolysis at $380^{\circ} \mathrm{C}$.
\end{abstract}

Keywords: Durian peel, liquid smoke, pyrolysis, acetic acid, phenol

(c) RASĀYAN. All rights reserved

\section{INTRODUCTION}

Indonesia is a country with abundant resources, one of which is durian. The Province of Aceh is rich in durian, producing approximately 17,620 tonnes annually, which represents approximately $10 \%$ of the national durian production in Indonesia ${ }^{1}$. This high production results in waste and has an environmental impact. The increase in durian production is parallel to the volume of the resulting waste. Without proper handling, this might lead to air pollution, diseases, and a decrease in the cleanliness of cities, among other concerns. Durian peel waste is not usually handled well: people simply throw it away in their neighborhoods without any treatment until it is burnt or decomposes. Durian peel biomass contains a high level of cellulose (50-60\%) and a low level of lignin and starch $(5 \% \text { each })^{2}$. The high level of cellulose in durian peel has the potential to be used as raw materials for producing liquid smoke. The resulting liquid smoke can be used as a natural preservative for food, such as fish, tofu, and noodles ${ }^{3-8}$. It can also be used as latex coagulants and as a biopesticide to reduce termites' impact on wood.

Previous studies have investigated the characteristics of liquid smoke from various biomass waste materials, such as palm kernel oil, sugar cane, and coconut shells ${ }^{9-11}$; however, only a few studies have examined the characteristics of liquid smoke produced at various temperatures. The knowledge about the effect of the pyrolysis temperature on the resulting liquid smoke is significant because temperature differences can result in different chemical compositions. In addition, if the pyrolysis temperature is too high and uncontrolled (above $400^{\circ} \mathrm{C}$ ) it will result in carcinogenic components, such as benzopyrones. 
This research aimed to characterize the various chemical compounds contained in liquid smoke obtained from durian peel pyrolysis at moderate temperatures using the slow pyrolysis method.

\section{EXPERIMENTAL}

The present study used the same methodology reported in the previous research ${ }^{5,12}$. The liquid smoke was produced in a $5 \mathrm{~kg}$ capacity, stainless steel pyrolysis reactor. The durian peel samples were taken from several sellers in Banda Aceh, and then weighed to identify their fresh weight. The waste was then dried in the sun for one day. As raw materials, $3 \mathrm{~kg}$ of the dry outer and inner peel was placed into the reactor, and then the samples underwent pyrolysis at $300^{\circ} \mathrm{C}, 340^{\circ} \mathrm{C}$, and $380^{\circ} \mathrm{C}$. The resulting smoke was condensed to produce grade 3 liquid smoke, tar, and charcoal. The liquid smoke was analyzed using gas chromatography-mass spectrometry (GCMS-QP2010, SHIMADZU) and high-performance liquid chromatography (HPLC, HITACHI L-4200H).

\section{RESULTS AND DISCUSSION}

\section{Composition Analysis of Liquid Smoke from Durian Peel using GC-MS}

GC-MS was used to analyze the composition within the liquid smoke obtained from each of the different pyrolysis temperatures since temperature plays a significant role in the resulting composition. In turn, this composition becomes one of the parameters that determine the quality of liquid smoke. The composition usually consists of phenol, carboxylate acid, furan, lactone, and alcohol. These compounds come from the decomposition of cellulose, hemicellulose, lignin, and other wood components. According to Yang et al. ${ }^{13}$, lignin is difficult to decompose at a low temperature, and it takes a long time to complete the process. Hemicellulose is easy to decompose at temperatures ranging from $200^{\circ} \mathrm{C}$ to $315^{\circ} \mathrm{C}$ (peaking at $268^{\circ} \mathrm{C}$ ) and cellulose decomposes at $350^{\circ} \mathrm{C}$. The decomposition mechanism is shown in Fig. $-1^{14}$. The GCMS analysis showed that the liquid smoke from the pyrolysis at $300^{\circ} \mathrm{C}, 340^{\circ} \mathrm{C}$, and $380^{\circ} \mathrm{C}$ contained 18 , 14 , and 21 compounds respectively. These results are different from those reported for liquid smoke from the pyrolysis of coconut shells at $400^{\circ} \mathrm{C}$, from which 14 compounds were found ${ }^{9}$. Oramahi and Diba ${ }^{15}$ found 14 compounds in liquid smoke from the pyrolysis of durian peel at $350^{\circ} \mathrm{C}$.

As seen in Table 1 , the liquid smoke from pyrolysis at $300^{\circ} \mathrm{C}$ primarily produced acetic acid $(36.37 \%)$ and, to a lesser degree, 2-butanone, 3-hydroxy-(CAS) acetoin, piperidine, 1-methyl-(CAS) nmethylpiperidine, and 2-propyl-2-pentenal (more than 5\% each). A few other compounds were also present in small amounts. As seen in Table 2, the chemical compounds in liquid smoke from pyrolysis at $340^{\circ} \mathrm{C}$ primarily produced acetic acid $(52.7 \%)$ and, to a lesser degree, 2-furanmethanol (CAS) furfuryl alcohol, carbamic acid, phenyl ester (CAS) phenyl carbamate and carbamic acid, and phenyl ester (CAS) phenyl carbamate (more than 5\% each). The rest of the compounds were derivative compounds. As seen in Table 3, the chemical compounds in liquid smoke from pyrolysis at $380^{\circ} \mathrm{C}$ produced acetic acid $(37.59 \%)$, as well as 2-oxepanone (CAS) caprolactone, and phenol (more than 5\% each).

Only a small amount of other compounds were detected. Changes in the percentage of acetic acid production $\left(36.37 \%\right.$ at $300^{\circ} \mathrm{C}, 52.7 \%$ at $340^{\circ} \mathrm{C}$, and $37.59 \%$ at $\left.380^{\circ} \mathrm{C}\right)$ could possibly be due to the fact that pyrolysis that leads to the degradation of cellulose and hemicellulose to form acetic acid occurs at $240-350^{\circ} \mathrm{C}$. At $300^{\circ} \mathrm{C}$, cellulose and hemicellulose have not yet completely decomposed, while at $380^{\circ} \mathrm{C}$ these compounds fully decompose. At $340^{\circ} \mathrm{C}$, the large amount of acetic acid is possibly due to the complete decomposition of cellulose and hemicellulose.

Tables-1, 2 and 3 show that there were differences in the resulting chemical compounds (acetic acid, phenol, furan, and others) because of the pyrolysis temperature at which lignin, cellulose, and hemicellulose decompose. The subsequent testing showed that, after distillation (to purify liquid smoke to grade 1), the acetic acid percentage increased. This was probably because some of the compounds with high boiling points were not vaporized. The cellulose and hemicellulose in durian peel will form acetic acid and its derivatives during pyrolysis. The analysis results showed that polycyclic aromatic hydrocarbons (PAHs) and benzopyrene were not found in the liquid smoke, probably because the pyrolysis temperature was lower than $400^{\circ} \mathrm{C}$. According to Stolyhwo and Sikorski ${ }^{16}$, pyrolysis conducted at $300-400^{\circ} \mathrm{C}$ can result in a 10 -fold decrease in the content of PAH. 
(1)<smiles>CC12CC(C(O)C1O)C(C)(C)C(CO)O2</smiles>

(Cellulose unit)
(2)

(3)<smiles>C1CCCCC1</smiles>

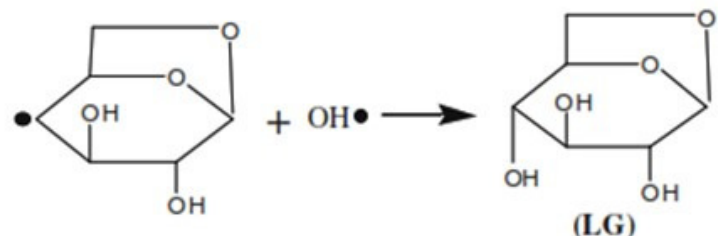

(LG)<smiles>CCC(O)C(O)C(O)C(O)CO</smiles>

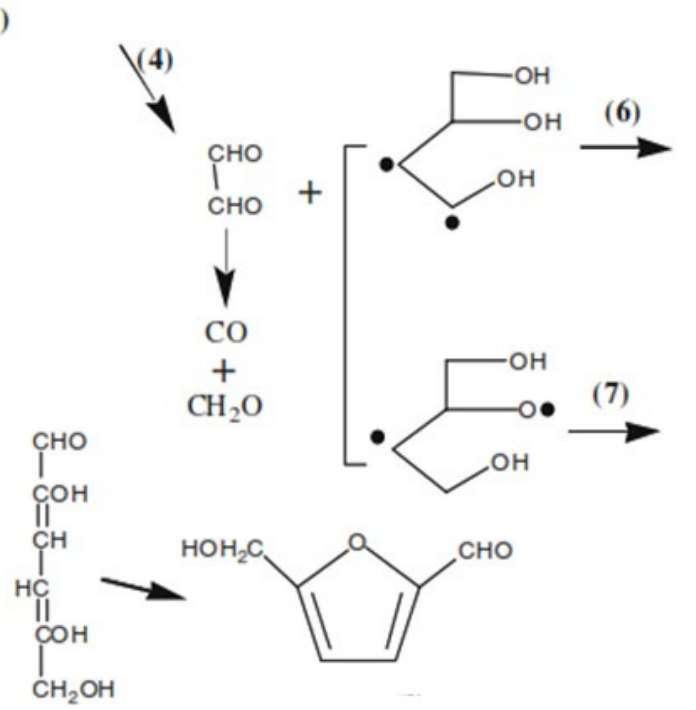

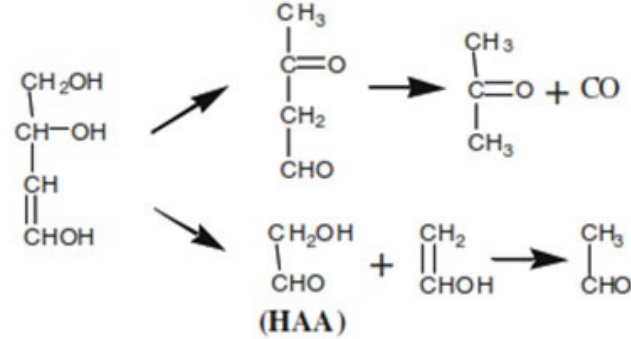

Fig.-1: The decomposition mechanism of cellulose (adopted from ref. 14)

Table-1: Chemical Composition of Liquid Smoke from the Pyrolysis of durian Peel at $300^{\circ} \mathrm{C}$

\begin{tabular}{c|l|c}
\hline No. & \multicolumn{1}{|c}{ Name } & Area $(\%)$ \\
\hline 1. & 1,1,4,4-Tetradeuteriotertamethylenediamine & 1.22 \\
\hline 2. & Acetic acid (CAS) ethylic acid & 36.37 \\
\hline 3. & Pyridine (CAS) azine & 1.04 \\
\hline 4. & 2-Butanone, 3-hydroxy- (CAS) acetoin & 7.97 \\
\hline 5. & 5-Hexen-2-one (CAS) allylacetone & 2.21 \\
\hline 6. & Pyridine, 2-methyl- (CAS) 2-methylpyridine & 1.53 \\
\hline 7. & 2(3H)-Furanone, dihydro- (CAS) butyrolactone & 4.27 \\
\hline 8. & 1-Pentyn-3-one, 4-methyl- (CAS) 2-methyl-3-oxo-4-pentyne & 2.41 \\
\hline 9. & Piperidine, 1-methyl- (CAS) n-methylpiperidine & 8.54 \\
\hline 10. & Cyclopentanone, 2,5-dimethyl- (CAS) 2,5-dimethyl cyclopentanone & 5.35 \\
\hline 11. & Phenol, 4-methyl- (CAS) p-cresol & 4.63 \\
\hline 12. & 2-Propyl-2-pentenal & 5.40 \\
\hline 13. & o-Methoxybenzyl alcohol & 1.76 \\
\hline 14. & Pentylamine, n-isopentyl-n-nitroso- (CAS) pentylisopentylnitrosamine & 0.86 \\
\hline 15. & 1,2-Benzenedicarboxylic acid, monobutyl ester (CAS) monobutyl phthalate & 1.07 \\
\hline 16. & Phenol, 2,6-dimethoxy- (CAS) 2,6-dimethoxyphenol & 2.60 \\
\hline 17. & Ethane, 1,1,1-triethoxy- (CAS) triethyl orthoacetate & 3.86 \\
\hline 18. & 2-methyl-3-oxo-butyronitrile & 1.51 \\
\hline
\end{tabular}


RASĀYAN J. Chem.

Vol. 11 | No. 2 |871 - 876 | April - June | 2018

Table-2: Chemical Composition of Liquid Smoke from the Pyrolysis of durian Peel at $340^{\circ} \mathrm{C}$

\begin{tabular}{c|l|c}
\hline No & \multicolumn{1}{|c}{ Name } & Area (\%) \\
\hline 1. & Acetic acid, cyano- (CAS) cyano-acetic acid & 0.10 \\
\hline 2. & 2-Isononenal (CAS) branched chain 2-nonenal & 1.48 \\
\hline 3. & 2-Butanone, 3-hydroxy- (CAS) acetoin & 1.10 \\
\hline 4. & 3-Hexanol, 2,4-dimethyl- (CAS) 2,4-dimethyl-3-hexanol & 0.22 \\
\hline 5. & Acetic acid (CAS) ethylic acid & 52.7 \\
\hline 6. & 2-Furanmethanol (CAS) furfuryl alcohol & 5.24 \\
\hline 7. & 2(3H)-Furanone, dihydro- (CAS) butyrolactone & 4.03 \\
\hline 8. & Carbamic acid, phenyl ester (CAS) phenyl carbamate & 9.29 \\
\hline 9. & 9-Oxabicyclo[6.1.0]nonan-4-one (CAS) 4-oxo-9-oxabicyclo[6.1.0]nonane & 6.33 \\
\hline 10. & Butanal, 3-hydroxy-(CAS) 3-hydroxybutanal & 3.27 \\
\hline 11. & 3-oxo-.alpha.-damascone & 1.67 \\
\hline 12. & 2h-pyran-2-one-6-d, tetrahydro-6-d-4-hydroxy-4-methyl- & 0.37 \\
\hline 13. & Phenol, 2,6-dimethoxy- (CAS) 2,6-dimethoxyphenol & 1.45 \\
\hline 14. & 2-D-2-pentadecyl-1,3-dioxolane & 0.57 \\
\hline
\end{tabular}

Table-3: Chemical Composition of Liquid Smoke from the Pyrolysis of durian Peel at $380^{\circ} \mathrm{C}$

\begin{tabular}{|c|c|c|}
\hline No & Name & Area $(\%)$ \\
\hline 1. & Carbon dioxide (CAS) dry ice & 0.48 \\
\hline 2. & 2-Propanone (CAS) acetone & 0.40 \\
\hline 3. & Acetic acid (CAS) athylic acid & 37.59 \\
\hline 4. & 2-Oxepanone (CAS) caprolactone & 5.68 \\
\hline 5. & Ethanol, 2-(1-methylethoxy)- (CAS) 2-isopropoxyethanol & 0.82 \\
\hline 6. & 2,4-Pentadienenitrile (CAS) cyanobutadiene & 1.49 \\
\hline 7. & Benzenamine (CAS) aniline & 0.47 \\
\hline 8. & 2,4-Hexadienal (CAS) sorbaldehyde & 7.10 \\
\hline 9. & 2(3H)-Furanone, dihydro- (CAS) butyrolactone & 3.1 \\
\hline 10. & 2-(3,5-dimethyl-1-pyrazolyl) succinic acid & 2.81 \\
\hline 11. & Phenol (CAS) izal & 8.19 \\
\hline 12. & Spiro[2.4]heptan-5-one & 2.80 \\
\hline 13. & 2,5-Dimethylcyclopentanone $\mathrm{b}$ & 3.31 \\
\hline 14. & Phenol, 2-methyl- (CAS) o-cresol & 3.78 \\
\hline 15. & Phenol, 2-methoxy- (CAS) guaiacol & 4.88 \\
\hline 16. & 2-Cyclopenten-1-one, 5-hydroxy-2,3-dimethyl- (CAS) & 6.78 \\
\hline 17. & 2-Methoxy-4-methylphenol & 1.46 \\
\hline 18. & 2-Hexanone, 3,3-dimethyl- (CAS) 3,3-dimethyl-2-hexanone & 1.63 \\
\hline 19. & Phenol, 2,6-dimethoxy- (CAS) 2,6-dimethoxyphenol & 1.54 \\
\hline 20. & 2-Acetyl-2-methyl-succinonitrile & 0.39 \\
\hline 21. & L-Serine (CAS) serine, L- & 1.04 \\
\hline
\end{tabular}

\section{Analysis of the Phenol and Acetic Acid Content}

In the present study, phenol was identified as the second largest compound contained in liquid smoke. It plays a significant role in providing flavor and taste, and it also has antimicrobial properties. Phenol results from the thermal degradation of lignin and cellulose by aliphatic compounds ${ }^{17}$.

Acetic acid has antibacterial properties; in a low $\mathrm{pH}$ environment, it causes enzyme denaturation and unstable permeability in bacterial cells, thereby hindering bacterial growth. The antimicrobial properties of acetic acid are dependent on its concentration, its $\mathrm{pH}$, the environment, the contact temperature, and the bacteria species or strain. In addition, acetic acid also determines the taste, flavor, and shelf life of a smoke product. Table-4 shows the content of phenol and acetic acid that was determined using HPLC.

The phenol content in liquid smoke produced from durian peel was analyzed using HPLC. The decrease in phenol content was possibly due to the fact that it was further decomposed into other compounds at $340^{\circ} \mathrm{C}$ and $380^{\circ} \mathrm{C}$. The amount and quality of phenol depend on the amount of lignin in the raw materials 
and the pyrolysis temperature ${ }^{11}$. Lignin is degraded at $280-500^{\circ} \mathrm{C}$ resulting in phenol. Ratnawati ${ }^{18}$ showed that grade 3 liquid smoke obtained from the pyrolysis of palm oil kernel at $400^{\circ} \mathrm{C}$ contained $12.9 \%$ phenol. Darmadji and Izumimoto ${ }^{19}$ stated that liquid smoke obtained from the pyrolysis of coconut shells at $400^{\circ} \mathrm{C}$ contained $4.13 \%$ phenol, while palm oil kernel contained $35.09 \%$ phenol at $500^{\circ} \mathrm{C}$ pyrolysis ${ }^{10}$. Budagara et al. ${ }^{11}$ reported that the combination of three types of raw materials, coconut, coconut shells, and cinnamon, contained $0.2-2.9 \%$ phenol.

As seen in Table-4, the acetic acid content was $4.19 \%$ at $300^{\circ} \mathrm{C}$ and $3.40 \%$ at $340{ }^{\circ} \mathrm{C}$, which then increased to $8.3 \%$ at $380^{\circ} \mathrm{C}$. These values are very similar to the results reported in previous research studies that used coconut shells and oil palm kernel ${ }^{5}$. Darmadji Izumimoto ${ }^{19}$ found that liquid smoke from the pyrolysis of coconut shells at $400^{\circ} \mathrm{C}$ contains $10.2 \%$ acetic acid. The liquid smoke from cinnamon and coconut husk at $300^{\circ} \mathrm{C}$ pyrolysis contained $0.03 \%$ and $0.51 \%$ acetic acid, respectively ${ }^{11}$. Saloko et al. ${ }^{7}$ found that liquid smoke from commercial coconut shells contained $6.72 \%$ acetic acid.

Table- 4: The Content of Phenol and Acetic Acid

\begin{tabular}{c|c|c}
\hline Pyrolysis Temperature $\left({ }^{\circ} \mathrm{C}\right)$ & Phenol & Acetic Acid \\
\cline { 2 - 3 } & $\%$ & 4.19 \\
\hline 300 & 2.08 & 3.40 \\
\hline 340 & 0.79 & 8.51 \\
\hline
\end{tabular}

\section{CONCLUSION}

The GC-MS analysis of the liquid smoke from the pyrolysis of durian peel at $300^{\circ} \mathrm{C}, 340^{\circ} \mathrm{C}$, and $380^{\circ} \mathrm{C}$ showed that the acetic acid content was $4.19 \%, 3.40 \%$, and $8.51 \%$ respectively. The highest phenol content $(2.08 \%)$ was found at $300^{\circ} \mathrm{C}$. The presence of phenol and acetic acid means that liquid smoke from durian peel has the potential to be used as a natural food preservative and a biopesticide.

\section{ACKNOWLEDGMENT}

The authors would like to acknowledge and thank the Ministry of Research, Technology, and Higher Education of Indonesia and Syiah Kuala University for the research funding.

\section{REFERENCES}

1. Badan Pusat Statistik dan Direktorat Jenderal Horikultura. 2011-2015, Produktivitas Durian Menurut Provinsi (2016).

2. R. Prabowo, Jurnal Mediagro Ilmu-Ilmu Pertanian., 5(1), 52 (2009).

3. Zuraida, I. Sukarno and S. Budijanto, Int. Food Res. J., 18, 405 (2011).

4. M.D. Guillen and M.L. Ibargoitia, J. Agr. Food Chem., 46(4), 1276 (1998), DOI: 10.1021/jf970952x.

5. M. Faisal , A. Gani, Husni and H. Daimon, Int. J. GEOMATE., 13(37), 147 (2017), DOI:10.21660//2017.37.2734.

6. L.C. Doherty and M. A. Cohn, Seed. Sci. Res., 10, 415 (2000), DOI:10.1017/S0960258500000465.

7. S. Saloko, P. Darmadji, B. Setiaji and Y. Pranoto, Food Biosci., 7, 71 (2014), DOI:10.1016/j.fbio.2014.05.008.

8. M. Faisal, T. Chamzurni and H. Daimon, Int. J. GEOMATE., 14(43), 36 (2018), DOI: $10.21660 / 2018.43 .3531$.

9. S.S. Achmadi, D.W. Harsi and A. Ihsan, Jurnal Teknologi dan Industri Pangan. 26(1), 1979 (2015), DOI : 10.6066/jtip.2015.26.1.1.

10. D. Ardila, Tamrin, W. Basuki and M. Eddyanto, J. Chem Mater. Res., 7(4), 71(2015).

11. K. Budagara, Arnim, M.Yetti and B. Usman, Int. J. Adv. Sci. Eng. Inform Technol., 6(3), 306(2016).

12. M. Faisal, A. Gani, Husni, A. Baihaqi and H. Daimon, J. Eng. Appl. Sci., 11(12), 2587(2016).

13. Y.B. Yang, A.N. Phan, C. Ryu, V. Sharifi and J. Swithenbank, Fuel, 86, 169 (2007), DOI: 10.1016/j.fuel.2006.07.012. 
RASĀYAN J. Chem.

Vol. 11 | No. 2 |871 - 876 | April - June | 2018

14. D.K. Shen and S. Gu, Bioresour. Technol., 100, 6496 (2009), DOI: 10.1016/j.biortech.2009.06.095.

15. H.A. Oramahi and F. Diba, Procedia Environmental Sciences, 17, 60(2013), DOI: 10.1016/j.proenv.2013.02.012

16. A. Stolywho and Z.E. Sikorski, J. Food Chem., 91, 303(2005), DOI: 10.1016/j.foodchem.2004.06.012.

17. J.A. Pino, J. Food Chem., 153, 81 (2014).

18. S.H. Ratnawati, Jurnal Teknik Kimia Institut Teknologi Indonesia 12(1) 8 (2010).

19. P. Darmadji and M. Izumimoto, J., Meat Sci., 38, 243 (2010).

[RJC-3035/2018] 